\title{
Anti-radical Properties of the Aqueous Extract from the Trunk Bark of Crateva adansonii (Capparaceae) and their role in the Inhibition of $\alpha$-amylases and $\alpha$-glucosidases Activities during the Carbohydrate Digestion
}

\author{
Ernest Rodrigue Talla ${ }^{1}$, Fidèle Ntchapda ${ }^{1}$, Emmanuel Talla $^{2}$, \\ David Miaffo ${ }^{3}$ and David Romain Azambou Kemeta ${ }^{1}$
}

\author{
${ }^{1}$ Department of Biological Sciences, ${ }^{2}$ Department of chemistry, Faculty of Science, University \\ of Ngaoundéré, Cameroon, P.O. Box 454, Ngaoundéré, Cameroon \\ ${ }^{3}$ Department of Life and Earth Sciences, Higher Teachers' Training College, University of \\ Maroua, Cameroon, P.O. Box 55, Maroua, Cameroon
}

*Corresponding author

\section{Keywords \\ Crateva adansonii, antiradical, $\alpha$-amylases, $\alpha$-glucosidases, diabetes}

Article Info

Accepted: 25 May 2021 Available Online: 10 June 2021

\section{A B S T R A C T}

Crateva adansonii is a plant species belonging to the family; Capparaceae, with multiple therapeutic uses in the traditional settings, including diabetes. The objective of this study was to evaluate the antiradical and anti-hyperglycaemic properties of the aqueous extract of the bark of the trunk of Crateva adansonii. The anti-hyperglycaemic properties of the extract was evaluated by the inhibition test of $\alpha$-amylase and $\alpha$-glucosidase enzymes in vitro confirmed by an in vivo study, on starch and sucrose tolerance tests using acarbose as witness. Indeed, during the starch and sucrose tolerance tests, 50 rats previously fasted without water for 16 hours were divided into 5 groups of 4 rats each and then their blood glucose levels were tested. Ten (10) minutes after pre-treatment with distilled water $(10 \mathrm{ml} / \mathrm{kg})$, acarbose $(10 \mathrm{mg} / \mathrm{kg})$ and the extract at doses of 200,250 and $300 \mathrm{mg} / \mathrm{kg}, 3 \mathrm{~g} / \mathrm{kg}$ of starch or sucrose was administered to each rat and their blood glucose levels were tested every 30 minutes for 2 hours. Anti-radical activity was tested by DPPH, ABTS and the antioxidant was examined using the FRAP tests. Phytochemical analysis of the aqueous extract of the bark of the trunk of Crateva adansonii shows the presence of polyphenols, tannins, flavonoids, triterpenes and anthraquinones. However, it is void of alkaloids. In addition, the total contents of polyphenols, flavonoids, and condensed tannins were quantified at $7 \pm 0.5 \mathrm{mg} \mathrm{Eq} \mathrm{GA} / \mathrm{g} \mathrm{ES}, 100.5 \pm 3 \mathrm{mg} \mathrm{Eq} \mathrm{QC/g} \mathrm{ES} \mathrm{and}$ $20 \pm 2.8 \mathrm{mg} \mathrm{Eq} \mathrm{C} / \mathrm{g}$ ES respectively. The results showed thatthe extract significantly reduce

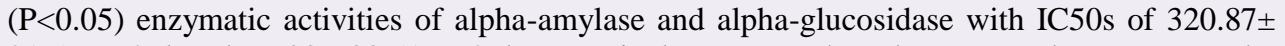
$21.59 \mu \mathrm{g} / \mathrm{ml}$ and $97.03 \pm 33.51 \mu \mathrm{g} / \mathrm{ml}$ respectively. For starch and sucrose tolerance tests, the extract at doses of $250 \mathrm{mg} / \mathrm{kg}$ and $300 \mathrm{mg} / \mathrm{kg}$ resulted in a significant decrease in blood glucose level at $60 \mathrm{~min}, 90 \mathrm{~min}$ and $120 \mathrm{~min}$ compared to the control group. The extract also has a good scavenging activity of DPPH free radicals (IC50=30 $\pm 0.1 \mu \mathrm{g} / \mathrm{ml})$, ABTS $^{\circ}(\mathrm{IC} 50=30 \pm 0.2$ ) and a good reducing power towards ferrous ions $(\mathrm{EC} 50=290 \pm 5 \mu \mathrm{g} / \mathrm{ml}$ ). These results effectively show that the aqueous extract of the bark of the trunk of Crateva adansonii possesses antiradical, antioxidant and anti-hyperglycaemic properties, confirming the use of this plant by phytotherapists in the treatment of diabetes. 


\section{Introduction}

Diabetes is a chronic disease that occurs when the pancreas does not produce enough insulin or the body does not properly use the insulin it produces $^{(1)}$. The pancreas regulates the concentration of blood sugar level, resulting to an increase in the concentration of glucose in the blood (hyperglycaemia), which over time leads to severe damage of many organs in the system, particularly nerves and blood vessels $^{(2)}$.

Diabetes is a major health problem that has reached alarming proportions. Currently, nearly half a billion people worldwide are living with diabetes and these numbers are clearly increasing every year ${ }^{(3)}$. Indeed, globally and in 2019, about 463 million people were living with diabetes and by 2030 , about 578 million people will have diabetes and 700 million by 2045 with a $51 \%$ increase if nothing is done ${ }^{(3)}$. In Africa, according to the International Diabetes Federation, 19 million people were living with diabetes in 2019 and by 2045 , about 47 million Africans will be living with diabetes ${ }^{(3)}$. In 2019 alone, 1.3 million Cameroonians were living with diabetes and by 2040 , more than 02 million Cameroonians will be diabetic ${ }^{(3)}$.

Diabetes mellitus is the sixth leading cause of death in the world ${ }^{(4)}$. It is responsible for $9 \%$ of mortality that is more than 4 million adult patients worldwide in 2019 and more than 13 thousand in Cameroon ${ }^{(3)}$.

Various studies have shown that diabetes mellitus is associated with an increase in the production of free radicals on one hand, and a decrease in antioxidant potential on the other hand, leading to oxidative stress. Thus, the causes of the complications and the pathologies associated with diabetes are on the one hand due oxidative mechanisms because of the chronic state of oxidative stress causing a change in biological molecules, and also due to the deleterious pathways of cells activated with $\operatorname{ROS}^{(5,6)}$.

One of the therapeutic approaches to treat type 2 diabetes is to decrease postprandial hyperglycaemia by delaying and reducing the digestion and absorption of ingested carbohydrates in the gastrointestinal tract ${ }^{(7)}$ through the administration of an oral dose of antidiabetic drugs; $\alpha$-glucosidase inhibitors such as miglitol and acarbose. These drugs inhibit the $\alpha$-glucosidase enzymes of the brush border of the small intestine (maltase, isomaltase and sucrase), thereby decreasing the degree of carbohydrate digestion and absorption. Unfortunately, this class also contains molecules that have different side effects, mainly flatulence, bloating and diarrhoea ${ }^{(8)}$. Also, it is expensive and not advisable for people at risk and difficult to access in some areas. These limitations lead to nearly $70 \%$ of the world's population and $80 \%$ of the African population to turn to herbal medicine to solve their health problems ${ }^{(7)}$.

Several herbal medicines have been used in different medicinal systems for the treatment and management of different diseases ${ }^{(9)}$. In Cameroon, several plants have shown their anti-diabetic properties; more specifically, in their inhibitory potential on the activity of $\alpha$ amylase and $\alpha$-glucosidase enzymes. Despite studies conducted on these multiple antidiabetic plants, the prevalence of diabetes is increasing considerably, hence the need of expanding research to highlight other plant species with anti-diabetic potential, which can improve treatment and provide patients with a wide range of solutions. For this study, we chose Crateva adansonii, a plant of the Capparaceae family used in African traditional medicine to treat abscesses, wounds, bacterial infections and rheumatism ${ }^{(10)}$ as well as in Cameroon in the treatment of Diabetes. $C$. adansonii leaves have antihyperglycaemic 
properties on the D glucose tolerance test and antioxidant properties (11). However, no scientific study on the anti-free radical properties and on the inhibition test of alpha amylase and alpha glucosidase enzyme activity has been conducted on the aqueous extract of the bark of the trunk (AECA) of this plant. The objective of this study is therefore to evaluate the anti-free radical and antidiabetic properties of the aqueous extract of the bark of trunk of Crateva adansonii.

\section{Material and Methods}

\section{Plant material}

The plant material consists aqueous extract of the bark of the trunk of Crateva adansonii (AECA) collected in Guirlin, Mboulvouday district, Mayo-Kani Division of the Far North region of Cameroon in November 2019. The sample was identified at the National Herbarium of Cameroon, in comparison with the Biholong M 158 material of specimen number 7877 of the Herbarium Collection. The bark of the trunk of C.adansonii was then dried and ground in a mortar to obtain its powder.

\section{Phytochemical tests}

\section{Determination of total polyphenols}

The total content of phenol in C.adansonii extract is determined using the method of Khoudali and al., modified ${ }^{(12)}$. A solution of the extract of concentration $0.2 \mathrm{mg} / \mathrm{ml}$ was prepared in methanol. A volume of $200 \mu \mathrm{L}$ of this extract is collected in a test tube and then a volume of $200 \mu \mathrm{L}$ of Folin - Ciocalteu reagent $(1: 1)$ is added to it. Then $400 \mu \mathrm{L}$ of a carbonate solution $(\mathrm{Na} 2 \mathrm{CO} 3)$ prepared with $7.5 \mathrm{~g} / \mathrm{L}$ is added. The resulting mixture is incubated in the dark for 30min; and then, a volume of $2 \mathrm{ml}$ of this mixture is taken in a cuvette to read the absorbance at a wavelength of $765 \mathrm{~nm}$ against methanol taken as the control. Gallic acid with a concentration of $0.1 \mathrm{mg} / \mathrm{mL} ; \quad 0.08 \mathrm{mg} / \mathrm{mL} ; \quad 0.06 \mathrm{mg} / \mathrm{mL}$; $0.04 \mathrm{mg} / \mathrm{mL}$ and $0.02 \mathrm{mg} / \mathrm{mL}$ is used as a standard. By analogy with the extract, each of these concentrations is run in the same way as the extract. The results are expressed in $\mathrm{mg}$ gallic acid equivalent EAG/ $g$ extract ${ }^{(12)}$.

\section{Determination of flavonoids}

The content of flavonoid is determined using the protocol described by Bahorun and al., modified $^{(13)}$. As a result, $1 \mathrm{ml}$ of methanoic acid extract of the bark of the trunk of Crateva adansonii is then added to $1 \mathrm{ml}$ of a $2 \%$ prepared solution of $\mathrm{AlCl} 3$. After an hour and at room temperature, the absorbance is measured at $420 \mathrm{~nm}$. Quercetin is used as a reference compound to plot the calibration curve in the standard range performed in parallel under the same operating conditions of different concentrations $(0.1 \mathrm{mg} / \mathrm{mL}$; $0.08 \mathrm{mg} / \mathrm{mL} ; \quad 0.06 \mathrm{mg} / \mathrm{mL} ; \quad 0.04 \mathrm{mg} / \mathrm{mL}$ and $0.02 \mathrm{mg} / \mathrm{mL}$ ). The tests are repeated three times. The results are expressed as milligram of Quercetin equivalent per gram of the dry extract $^{(12)}$.

\section{Determination of tannins}

The content of tannin is determined according to the protocol described by Khoudali and al., modified $^{(12)}$, the tannin content of the extract is evaluated by the vanillin method. A $1 \mathrm{ml}$ of a solution of the extract with a concentration of $0.2 \mathrm{mg} / \mathrm{ml}$ is mixed with $5 \mathrm{ml}$ of the reagent solution ( $4 \mathrm{~g}$ of vanillin in a mixture made with $50 \mathrm{ml}$ of $37 \% \mathrm{HCl}$ and $50 \mathrm{ml}$ of ethanol). The mixture was incubated at $30^{\circ} \mathrm{C}$ for 20 minutes. At the end of the experiment, the absorbance is read at $500 \mathrm{~nm}$. The content of tannin in the extract is evaluated using a standard solution of $0.2 \mathrm{~g} \mathrm{~L}^{-1}$ catechic acid. The results were expressed as milligram equivalence of catechin $(\mathrm{EC} / \mathrm{g})$ per $1 \mathrm{~g}$ of the dry extract. 


\section{Evaluation of anti-free radical properties}

\section{DPPH (2,2-DiPhenyl-1-PicrylHydrazyl) test}

The DPPH anti-free radical capacity is measured according to the method described by Bozin and al., modified ${ }^{(14)}$. A volume of $0.1 \mathrm{~mL}$ of $C$. adansonii at different concentrations $(100,80,60,40,20 \mu \mathrm{g} / \mathrm{mL})$ are mixed with $2.9 \mathrm{~mL}$ of $0.04 \%$ DPPH. Ascorbic acid, used as a reference antioxidant, was also tested at these same concentrations.

After homogenisation, the mixture was incubated at room temperature in the dark for 30 minutes. For each concentration, the assays are tripled, the optical densities or absorbance are measured using a spectrophotometer at $517 \mathrm{~nm}$ and the antioxidant activities expressed as percentage inhibition (PI) are evaluated.

\section{ABTS- $\quad$ (2,2'-azino-bis-(3 ethyl- benzothiazoline-6-sulphonic acid) free radical test)}

The ABTS test is performed according to the method described by $\operatorname{Re}$ and al., ${ }^{(15)}$. Two solutions are prepared alongside an ABTS solution $(7 \mathrm{mM})$ and a potassium persulphate solution (Sigma Aldrich) $(2.4 \mathrm{mM})$ for a final concentration of $3.5 \mathrm{mM}$. The cationic radical ABTS $\bullet+$ is generated by mixing the two solutions in equivalent amounts (1:1). The mixture is allowed to react for 12 hours at room temperature in the dark (that is deprived of light).

The resulting solution is diluted to have an absorbance of 0.8 which is measured using a spectrophotometer at $734 \mathrm{~nm}$. The antioxidant activity is measured by adding 4 to $30 \mu \mathrm{L}$ of the aqueous extract of $C$. adansonii to a diluted solution of ABTS $\bullet+$ radical. The decrease in absorbance at $734 \mathrm{~nm}$ is measured until a plateau is reached.

\section{Ferric ions Reducing Antioxidant Parameter (FRAP) test}

The antioxidant ability of the extract of the bark of the trunk of Crateva adansonii was determined with the help of a dosage of the reducing antioxidant ability of the ferric ion according to the method described by Benzie and al., ${ }^{(16)}$ where ferric tripyridyltriazine is reduced to the blue ferrous form with a low $\mathrm{p}^{\mathrm{H}}$. The intensity of the blue colour was directly proportional to reducing power of antioxidants electron donors present in the samples in the test tube.

The antioxidant ability of the extract equivalent of ascorbic acid was calculated while extrapolating the values of the linear portion of the standard graph of the ascorbic acid is expressed in mg equivalent of ascorbic acid per mg of the extract ${ }^{(6)}$.

\section{Animals}

The animal material consists of fifty (50) adult male rats of Wistar strain (including 25 rats for the starch inhibition test and 25 for the sucrose inhibition test), aged between two (2) and three (03) months and weighing between 200 and $300 \mathrm{~g}$.

These animals were reared in the animal house of the Faculty of Sciences of the University of Ngaoundéré, under a normal light/dark cycle, at room temperature $(25 \pm 2 \mathrm{oC})$ and relative humidity $(40 \% \pm 10 \%)$ while respecting biological conditions. These animals were under the control of veterinary doctors from the School of Veterinary Medicine of the University of Ngaoundéré.

Before the start of the experiment, the animals were acclimatized for seven days in the Phytomedicinal, Health and Galenic Formulation Laboratory, where they had "ad libitum" access to water and food. 


\section{Evaluation of anti-hyperglycaemic properties}

\section{Inhibition activity of alpha amylase}

The test for inhibition of $\alpha$-amylase activity was performed according to the standard in vitro chromogenic inhibition procedure, modified by Bernfeld ${ }^{(17)}$. Indeed, a total of 500 $\mu \mathrm{l}$ of the extract or acarbose at different concentrations $(100,150,200,250$ and $300 \mu \mathrm{g}$ $/ \mathrm{ml})$ is added to $500 \mu \mathrm{l}$ of tris buffer $(0.02 \mathrm{M}$; $\mathrm{pH}=7)$ containing $\alpha$-amylase solution $(0.5$ $\mathrm{mg} / \mathrm{ml}$ ) and the whole was incubated at $25{ }^{\circ} \mathrm{C}$ for $20 \mathrm{~min}$. Subsequently, $250 \mu \mathrm{l}$ of $1 \%$ starch solution is added to each tube to start the reaction and the mixture is again incubated at $25^{\circ} \mathrm{C}$ for $10 \mathrm{~min}$. The reaction is stopped after the addition of $2 \mathrm{~mL}$ of a dye reagent $(3,5-$ dinitrosalicylic acid) to each tube. The test tubes are boiled in a water bath at $100{ }^{\circ} \mathrm{C}$ for 5 min and then cooled down to room temperature. The absorbance (A) is read at $540 \mathrm{~nm}$ using a spectrophotometer and the percentage inhibition (I\%) is calculated.

\section{Inhibition activity of alpha glucosidase}

The activity of alpha glucosidase enzyme inhibition test is evaluated using the method described by Kim and al., ${ }^{(18)}$.Infact, $50 \mu \mathrm{l}$ of the extract or acarbose solution at different concentrations $(100,150,200,250$ and $300 \mu \mathrm{g}$ $/ \mathrm{ml})$ are introduced into $100 \mu$ ltris buffer $(20$ $\mathrm{mM}$; $\mathrm{pH}$ 6.8) containing $100 \mu \mathrm{l}$ of $\alpha$ glucosidase solution $(0.01 \mathrm{mg} / \mathrm{ml})$ and preincubated at $25{ }^{\circ} \mathrm{C}$ for $10 \mathrm{~min}$. After preincubation, $50 \mu \mathrm{l}$ of $5 \mathrm{mM}$ substrate (pnitrophenyl- $\alpha$-D-glucopyranoside) is added to each tube to start the reaction. The mixture is then incubated at $37{ }^{\circ} \mathrm{C}$ for $15 \mathrm{~min}$. The reaction is stopped after the addition of $2 \mathrm{ml}$ of $500 \mathrm{mM} \mathrm{Na} 2 \mathrm{CO} 3$ to each tube. The absorbance of the yellowish solution is read at $400 \mathrm{~nm}$ using a spectrophotometer and the percentage inhibition and mean inhibition concentration (IC50) of the extract are calculated.

\section{Starch tolerance test}

In order to verify in vivo, the antihyperglycaemic effects of the aqueous extract of the bark of the trunk of Crateva adansonii, a starch tolerance test was performed in normal rats. The animals are divided and treated as follows:

Group 1 (control group) received distilled water $(10 \mathrm{ml} / \mathrm{kg}$ body weight);

Group 2 (reference group) received acarbose solution at a dose of $10 \mathrm{mg} / \mathrm{kg}$;

Groups 3, 4 and 5 received the extract at 200, 250 and $300 \mathrm{mg} / \mathrm{kg}$ respectively.

Ten (10) minutes after the rats' initial blood glucose levels ( $0 \mathrm{~min}$ ) were taken, followed by their treatment according to the abovementioned batches, each rat is orally given 3 $\mathrm{g} / \mathrm{kg}$ of starch solution. At the 30th, 60th, 90th and 120th minute after carbohydrate loading, the blood glucose level is measured.

\section{Sucrose tolerance test}

The sucrose tolerance test was performed in the same way as the starch tolerance test described above with the only difference that sucrose will be administered instead of starch at a dose of $4 \mathrm{~g} / \mathrm{kg}$ body weight.

\section{Statistical analysis}

The results are expressed as mean \pm standard deviation. Data analysis is performed using version 8.0. of Graph Pad Prism software. For the treatment of the dual variable data, twoway analysis followed by Tukey's test is used. In contrast, a one-way analysis followed by the Bonferroni test is used for the treatment of 
univariate data. The means are considered significant at the 5\% probability level.

\section{Results and Discussion}

Family of chemical compounds present in the AECA

Table 1 above shows the different families of chemical compounds present in the aqueous extract of $C$. adansonii. This shows, the extract of $C$. adansonii is rich in polyphenols, tannins, flavonoids, triterpenes and anthraquinones; however, it does not contain alkaloids.

\section{The content Flavonoid, Polyphenol and Tannin of AECA}

The determination of metabolites in the aqueous extract of the bark of the trunk of $C$. adansonii shows that the plant is very rich in flavonoids (201.236 mgEQ \pm 2.6 )(Fig. 1). In addition, the plant is also rich in polyphenols (70.23 mgEAG \pm 2 ) and tannin (47.87 mgEC $\pm 1.6)$.

Effect of AECA on the DPPH (2,2'diphenyl-1-picrylhydrazyl) radical reduction test

The results obtained from the DPPH radical reduction test reveal that the extract possesses a dose-dependent anti-radical activity (Fig. 2A).

At all tested concentrations, the extract significantly inhibited the $\mathrm{DPPH}^{\circ}$ radical. Infact, for concentrations ranging from 0.02 to $0.1 \mathrm{mg} / \mathrm{ml}$ the extract showed inhibitory powers of $65.73 \%$ to $86.41 \%$ respectively with an IC50 of $30 \pm 0.1 \mu \mathrm{g} / \mathrm{ml}$. For the same concentrations as the extract, a strong inhibitory power is recorded with vitamin C with values ranging from $87.88 \%$ to $96.23 \%$ respectively with a CI50 of $13 \pm 0.2 \mu \mathrm{g} / \mathrm{ml}$.
Effect of AECA on the ABTS $^{\circ}(2,2$ '-azinobis-(3 ethylbenzothiazoline-6-sulphonic acid)) reduction test

The $\mathrm{ABTS}+{ }^{\circ}$ cation radical inhibition test shows that ABTS was significantly inhibited at all concentrations tested and in a dosedependent manner (Fig. 2B). For concentrations ranging from 0.02 to $0.1 \mathrm{mg} / \mathrm{ml}$ vitamin $\mathrm{C}$ show a strong inhibitory potencies ranging from $78.99 \%$ to $95.32 \%$ with an IC50 of $10 \pm 0.1 \mu \mathrm{g} / \mathrm{ml}$. Similarly, the extract also showed strong inhibitory potencies ranging from $62.82 \%$ to $95.32 \%$ respectively for the same concentrations as vitamin C with a CI50 of $30 \pm 0.2 \mu \mathrm{g} / \mathrm{ml}$.

\section{Effect of AECA on the ferric ion reduction test (FRAP $=$ FerrousIons Reducing Antioxidant Parameter)}

Fig. 3below shows the percentage of the ferric ion reduction as a result of the concentration of extract. We notice on this figure that at the concentration of $0.1 \mathrm{mg} / \mathrm{ml}$, the reference showed a reducing power of $53.90 \%$ against a reducing power of $41.36 \%$ for the extract. At the maximum concentration of $0.5 \mathrm{mg} / \mathrm{ml}$, the reference shows an excellent reducing power of a value of $86.09 \%$ with an EC50 190 $\pm 10 \mu \mathrm{g} / \mathrm{ml}$. Similarly, at this concentration, the extract also showed a high reducing power of the order of $73.63 \%$ with an EC50 of $290 \pm 5$ $\mu \mathrm{g} / \mathrm{ml}$ (figure 4).

Effects of AECA on the inhibition of enzyme activity of alpha-amylase

The effect of aqueous extract of the bark of trunk of $C$. Adansonii (AECA) on the inhibition of enzyme activity of $\alpha$-amylase is shown in Fig. 4A below. This figure shows that the aqueous extract has a remarkable inhibitory effect on the enzyme activity of $\alpha$ amylase. For concentrations ranging from 100 to $300 \mu \mathrm{g} / \mathrm{ml}$, the extract showed an inhibition rate ranging from $16.26 \%$ to $46.48 \%$ i.e. an 
IC50 of $320.87 \pm 21.59 \mu \mathrm{g} / \mathrm{ml}$ against $32.28 \%$ to $65.04 \%$ obtained with acarbose i.e. an IC50 of $197.87 \pm 13.45 \mu \mathrm{g} / \mathrm{ml}$.

\section{Effects of AECA on the inhibition of alpha- glucosidase enzyme activity}

Fig.4B below shows the effect of the aqueous extract of the bark of the trunk of $C$. adansonii on the inhibition of $\alpha$-glucosidase enzyme activity. This figure shows that the aqueous extract also has a remarkable inhibitory effect on the activity of the $\alpha$-glucosidase enzyme. For concentrations ranging from 100 to $300 \mu \mathrm{g} / \mathrm{ml}$, the extract showed an inhibition rate ranging from $51.32 \%$ to $66.22 \%$, i.e. an IC50 of $97.03 \pm 33.51 \mu \mathrm{g} / \mathrm{ml}$, against $53.80 \%$ to $72.68 \%$ obtained with acarbose, i.e. an IC50 of $68.42 \mu \mathrm{g} / \mathrm{ml}$.

\section{Effect of AECAon starch and sucrose tolerance test.}

The starch tolerance test (Fig. 5A) shows that acarbose caused a significant $(\mathrm{p}<0.001)$ reduction in blood glucose levels in the reference group of $30.92 \%, 37.79 \%, 43.12 \%$ and $60.15 \%$ respectively, all-time compared to the control group. Like acarbose, compared to the control group, the $300 \mathrm{mg} / \mathrm{kg}$ extract showed a significant $(\mathrm{p}<0.001)$ reduction in blood glucose levels in the treated batch at the same time intervals $(27.14 \%, 35.71 \%, 35.70 \%$ and $54.77 \%$ ) respectively.

Like the starch tolerance test, the sucrose tolerance test (Fig. 5B) shows that the 300 $\mathrm{mg} / \mathrm{kg}$ extract resulted in significant $(\mathrm{p}<0.001)$ decrease in blood sugar levels (from $26.51 \%$, $37.67 \%$ to $47.38 \%$ at the 60th, 90th and 120th minute respectively).

Similarly, a significant $(\mathrm{p}<0.001)$ similar reduction in blood sugar levels to that of the extract was observed with acarbose $(25.58 \%$, $32.01 \%, 42.63 \%$ respectively at the same time interval).

Table.1 Family of chemical compounds present in the aqueous extract of the bark of the trunk of $C$. Adansonii

\begin{tabular}{|c|c|}
\hline Compounds & Results \\
\hline Polyphenols & + \\
\hline Tannins & + \\
\hline Flavonoids & + \\
\hline Triterpenes & + \\
\hline Alkaloids & - \\
\hline Anthraquinones & + \\
\hline
\end{tabular}

$(+)=$ Present

$(-)=$ Absent 
Fig.1 Thecontent of Polyphenols, flavonoids and tannins. Each bar represents the means \pm SD $(\mathrm{n}=3) . \mathrm{AECA}=$ Aqueous extract of the bark of the trunk of Crateva adansonii. $\mathrm{mgEC} / \mathrm{g}=\mathrm{mg}$ Catechin equivalent; $\mathrm{mgEAG} / \mathrm{g}=\mathrm{mg}$ Gallic acid equivalent; $\mathrm{mgEQ} / \mathrm{g}=\mathrm{mg}$ Quercetin equivalent

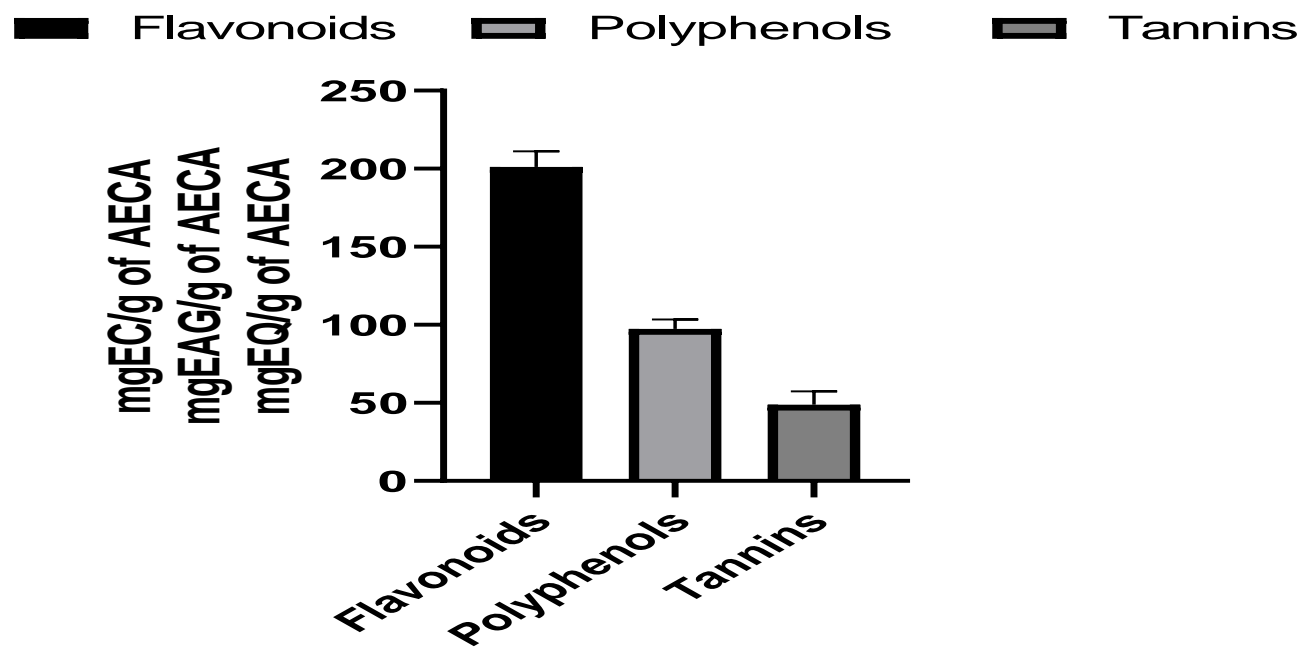

Fig.2 Effect of aqueous extract of $C$. adansonii bark of trunk on the inhibition percentage of DPPH- (A) and ABTS + (B) radical. All results are expressed as mean $\pm \mathrm{SD}(\mathrm{n}=3)$.

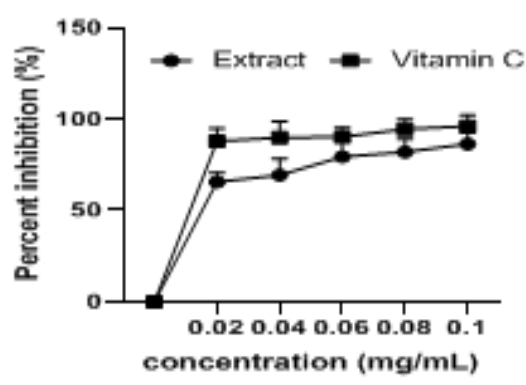

(A)

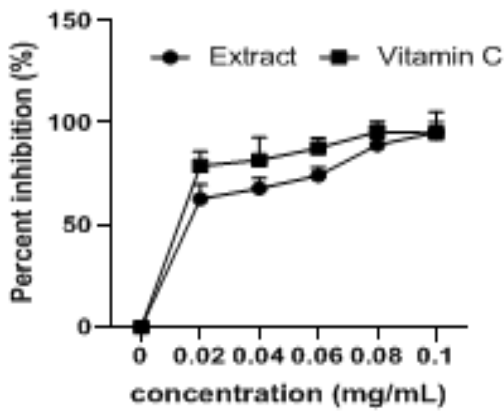

(B)

Fig.3 Reducing power of ferric ions in the aqueous extract of the bark of the trunk on C. adansonii. All results are expressed as mean $\pm \mathrm{SD}(\mathrm{n}=3)$.

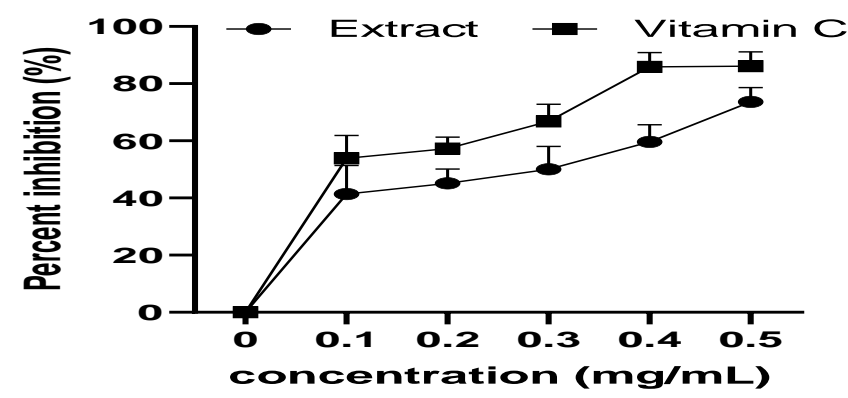


Fig.4 Effect of aqueous extract of the bark of the trunk of C. adansonii on inhibition of alpha amylase (A) and alpha glucosidase (B) enzyme activity. All results are expressed as mean \pm SD $(n=3) .\left({ }^{*} p<0.05\right)$ significant difference compare to $100 \mu \mathrm{g} / \mathrm{mL}$ of Acarbose. $\left({ }^{a} \mathrm{p}<0.05\right)$ significant difference compare to $100 \mu \mathrm{g} / \mathrm{mL}$ of Extract.

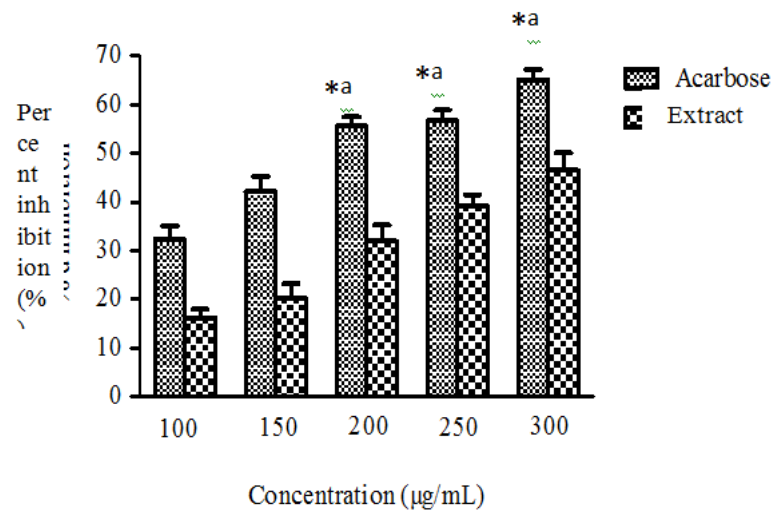

(A)

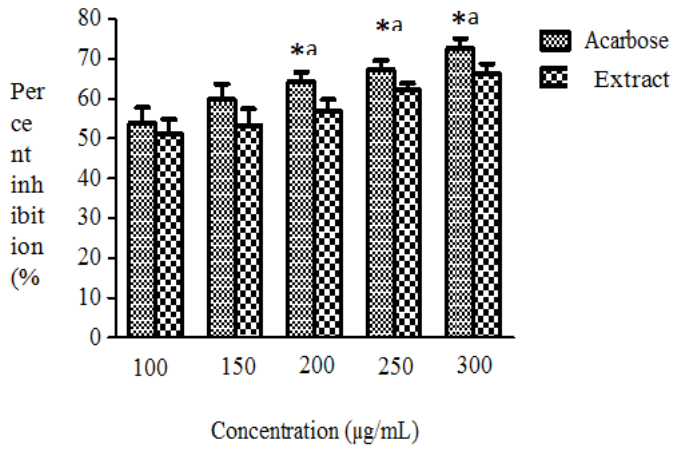

(B)

Fig.5 Starch (A) and sucrose (B) tolerance test. All results are expressed as mean \pm SD ( $n=6$ ). Data analysis was performed by two-way ANOVA followed by Bonferroni's test. (***p $<$ 0.001)highly significant decrease compare to the 30 min of normal control group. AECA: Aqueous extract of the bark of the trunk of Crateva adansonii.

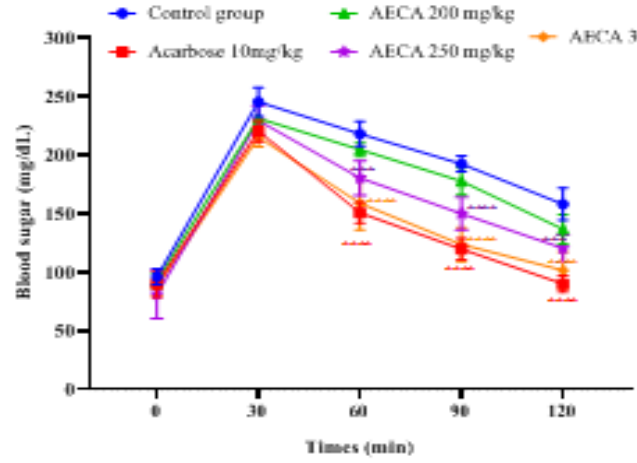

(A)

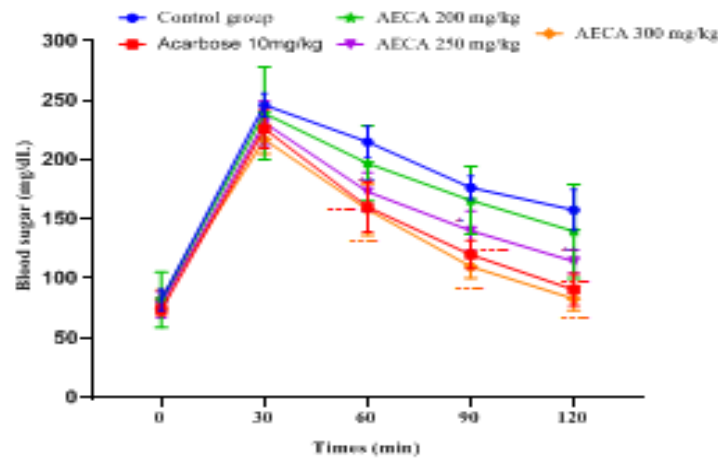

(B)

The quantitative analysis of the different compounds contained in the aqueous extract of the bark of the trunk of $C$. adansonii showed a significant presence of flavonoids (100.5 $\pm 3 \mathrm{mg}$ QC/g ES), polyphenols $(7 \pm 0.5$ $\mathrm{mg} \mathrm{GA} / \mathrm{g} \mathrm{ES})$ and condensed tannins $(20 \pm 2.8$ $\mathrm{mg} \mathrm{Cq} / \mathrm{g}$ ES). These chemical compounds could therefore be the source of the antidiabetic effects of the plant.

Inhibition tests of the enzymes $\alpha$-amylase and $\alpha$-glucosidase in vitro shows that the aqueous

extract of the bark of the trunk of $C$. adansonii, like acarbose, has strong concentration-dependent inhibitory properties. This observed alpha amylase enzyme inhibitory activity is attributed to the presence of phytochemical antioxidants including flavonoids, tannins and saponins which have been shown to inhibit $\alpha$-amylase activity and preserve $\beta$-cell integrity thus protecting against the development of type 2 diabetic insulin resistance ${ }^{(19)}$. 
However, in all cases, the extract produced a strong inhibition of $\alpha$-glucosidase (IC50 of $97.03 \pm 33.51 \mu \mathrm{g} / \mathrm{ml}$ ) compared to $\alpha$-amylase (IC50 of $320.87 \pm 21.59 \mu \mathrm{g} / \mathrm{ml}$ ). It therefore has the highest concentration-dependent inhibitory potential on $\alpha$-glucosidase enzyme activity than on $\alpha$-amylase enzyme activity. The inhibitory power of the enzymes can be due to the fact that the extract, like acarbose, has a form similar to that of the oligosaccharides resulting from the digestion of starch, and can therefore bind to the $\alpha$ glucosidase enzymes located on the brush border of the intestine, thus competitively inhibiting these enzymes in a dose-dependent manner. These results corroborate with those obtained by Miaffo and al., ${ }^{(20)}$ who showed that the aqueous extract of Combretummolle have an inhibitory activity on digestive enzymes ( $\alpha$-amylase and $\alpha$-glucosidase).

These observed $\alpha$-amylase and $\alpha$-glucosidase inhibitory enzyme activities can also be attributed to phenolic compounds, tannins and flavonoids which are potential inhibitory effects on alpha amylase and alpha glucosidase because they have the ability to bind to carbohydrates and proteins ${ }^{(21,22)}$.

Starch and sucrose tolerance tests show that acarbose and the extract at doses of $250 \mathrm{mg} / \mathrm{kg}$ and $300 \mathrm{mg} / \mathrm{kg}$ resulted in significant reduction in blood glucose levels at the $60^{\text {th }}$, $90^{\text {th }}$ and $120^{\text {th }}$ min. This significant reduction in blood glucose levels by the aqueous extract of $C$. adansonii aqueous extract suggests that it may play a role in decreasing glucose uptake by inhibiting the enzymatic activity of alphaamylases and alpha-glucosidases, which are important enzymes in the digestive process of complex dietary carbohydrates. From these results, it can be observed that there is a good correlation between the in vitro and in vivo tests. Furthermore, it seems that the richness of the aqueous extracts of $C$. adansonii in different metabolites participate in the decrease of the postprandial glucose level by increasing the peripheral usage of glucose. Thus, the observed anti-hyperglycaemic effect of $C$. adansonii extract can be attributed to the presence of phenols, flavonoids, tannins and saponins (23). Similarly, Fang and al., ${ }^{(24)}$ showed that the flavonoid-rich ethyl acetate fraction of Euonymus alatus would have stimulating properties on insulin released and would be at the origin of the hypoglycaemic effects of this plant in normoglycaemic mice and antihyperglycaemic effects in mice with type 2 diabetes.

The evaluation of the antioxidant activity was carried out using $\mathrm{DPPH}^{\circ}, \mathrm{ABTS}^{\circ}+$ and FRAP tests, which are the most widely used tests due to their simplicity and reproducibility. The results show that the extract has a concentration-dependent anti-radical activity. For radical scavenging activity using the $\mathrm{DPPH}^{\circ}, \mathrm{ABTS}^{\circ}{ }^{\circ}$ and FRAP assays, strong anti-free radical activity was recorded for both Vitamin $\mathrm{C}$ and the extract. However, at all concentrations, the percentage inhibition of Vit $C$ is slightly higher than that of the extract. This could be explained by the fact that Vitamin $\mathrm{C}$ is a reference molecule. These results corroborate those obtained by Kouadio and $a l .,{ }^{(25)}$ who observed that the percentage of inhibition of Trolox (reference "purified" molecule) is higher than that of the plant extracts at all concentrations. This observed antioxidant activity of $C$. adansonii extract could be explained by their richness in polyphenols substances. Li and al., ${ }^{(26)}$ showed that polyphenols and flavonoids are major contributors to the antioxidant property of plants, as they had the ability to scavenge free radical species and reactive forms of oxygen or prevent the decomposition of hydrogen peroxide into free radicals. The antioxidant effect of flavonoids (FLOH) is attributed to their low redox potential which makes them thermodynamically capable of reducing free radicals (R-), by a transfer of hydrogen atom from the hydroxyl groups $(\mathrm{OH})$. This reaction 
gives rise to the aroxyl radical (FLO-) and the stable radical molecule $(\mathrm{RH})$, the aroxyl radical FLO- will subsequently undergo a structural rearrangement, allowing the redistribution of the single electron on the aromatic ring and the stabilisation of aroxyl radicals ${ }^{(27)}$.

In conclusion, the aqueous extract of the bark of the trunk of $C$. adansonii possesses antioxidant properties proven by the ferric ion reduction test (FRAP), the DPPH anti radical test and ABTs. Similarly, this plant antihyperglycaemic properties proven by the enzyme activity of alpha amylase and alpha glucosidase inhibition test, confirmed by the sucrose and starch tolerance test. The results obtained in this study confirm the traditional use of this plant in the treatment of diabetes mellitus and its cardiovascular complications. In a future study, we will investigate the mechanism of action of this plant.

\section{Acknowledgement}

The authors are thankful to Higher Teachers' Training College, University of Ngaoundéré, Cameroon, for providing the facility to carry out the research. The authors also thank the Laboratory of the Medicinal Plants, Health and Galenic Formulation of the Department of Biological Sciences, University of Ngaoundéré.

\section{References}

1. World Health Organisation. AideMémoire Sur Le Diabète sucré. 2016;138:1

2. Kambouche N, Merah B, Derdour A, Bellahouel S, Bouayed J, Dicko A, Younos C, Soulimani R. Hypoglycemic and antihyperglycemic effects of Anabasis articulate(Forssk) Moq (Chenopodiaceae), an Algerian medicinal plant. African Journal of
Biotechnology 2009;8(20): 5589-5594.

3. International Diabetes Federation. Diabetes atlas. ninth ed. 2019. Brussels, Belgium.

4. Nash D, Koenig J, Novielli K, Liberoni R, Reisman M. The importance of the individualized pharmaceutical therapy in the treatment of diabetes mellitus. Dis. Manag 2001;4(1): 5-23.

5. Bonnefont-Rousselot D. The Role of Antioxidant Micronutrients in the Prevention of Diabetic Complications. Mol Diag Ther2004;3: 41-52. https://doi.org/10.2165/00024677200403010-00005

6. Singh R, Barden A, Mori T, Beilin L. Advanced glycation end products. a review. Diabetologia2001;44: 129-46.

7. Khacheba I, Djeridane A, Yousfi M. Twenty Traditional Algerian Plants Used in Diabetes Therapy as Strong Inhibitors of $\alpha$-Amylase Activity. International Journal of Carbohydrate Chemistry2014:12.

8. Halimi S, Debaty I, Vellaret L, Muller M. Les nouveaux traitements du diabète de type 2. LaRevue de la Médecine Interne2008;29:881-890.

9. Arulmozhi S, Papiya M M, Purnima A, Sathiya N L. Pharmacological activities of Alstonia Scholaris linn, Pharmacognosy Reviews 2007; 1(1):163-164.

10. Olou B A, Bio A, Deleke K E, Djego G J, Sinsin A B.Connaissances ethnobotaniques et valorisation de deux plantes antihypertensives (Carissa edulis L. et Crateva adansonii DC) au Sud et au Centre du Bénin (Afrique de 1'Ouest). Int. J. Biol. Chem. Sci. 2018;12(6):26022614. DOI: https://dx.doi.org/10.4314 /ijbcs.v12i6.11

11. Atchou K, Lawson E, Metowogo K, Bakoma B, Eklu G, Aklikokou K, Gbeassou M. Antihyperglycaemic and antioxydant activities of Crateva adansonii DC. ssP. adansonii leaves 
extract on ICR mice. Journal of Drug Delivery and Therapeutics 2020;(1-s):3038

12. Khoudali S, Benmessaoud D L, Essaqui A M, Zertoubi M, Azzi M, Bernaissa M. Etude de l'activité antioxydante et de l'action anti corrosion de l'extrait méthanolique des feuiles de palmier nain (Chamaerops humilis L.) du Maroc. Journal mater environ science 2014:20282508.

13. Bahorun T, Gressier B, Trotin F, Brunet C, Dine T, Vasseur J, Gazin J C, Pinkas M, Luyckx M, Gazin M. Oxygen species scavenging activity of phenolic extract from Hawthorn fresh plant organs and pharmaceutical preparations. Arzneimittel Forschung - Drug Research 1996;46:1086-1094.

14. Bozin B, Mimica-Dukic N, Samojlik I, Goran A, Igic R. Phenolics as antioxidants in garlic (Allium sativum L., Alliaceae) 》. Food Chemistry 2008;111(4): 925-929.

15. Re R, Pellegrini N, Proteggente A, Pannala A, Yang M, Rice-Evans C. Antioxidant activity applying an improved ABTS radical cation decolorization assay. Free Rad. Biol. Med. 1999;26:1231-1237.

16. Benzie I F F, Souche J J, Pejin B, Bogdanovic-Pristov J, Schutz K, Carle R, Schieber A. ABTS cation scavenging activity and total phenolic content of three species of moss 2012:70-76

17. Bernfeld P. Amylases, $\alpha$ and $\beta$. Methods in enzymology 1955:149-158

18. Kim J S, Kwom C S, Son K H. Inhibition of alpha-glucosidase and amylase by luteolin, a flavonoid. Biosci Biotechnol Biochem. 2000;64(11) :2458-61. Doi : 10.1271/bbb.64.2458.

19. Sarma A, Mallick A, Ghosh A. Free radicals and their role in different clinicalconditions: an over- view. Int $\mathbf{J}$ Pharm Sci Res. 2010;1:185-92
20. Miaffo D, Wansi S L, Poualeu K S L, Kuete FC. In vitro $\alpha$-Amylase and $\alpha$ Glucosidase Enzymes Inhibitory Effects of the Aqueous Extract of Combretum molle Twigs. International Journal of Toxicological and Pharmacological Research, 2015;7(2):74-79.

21. Poongunran J, Perera H K I, Fernando W, Jayasinghe L, Sivakanesan R. $\alpha$ Glucosidase and $\alpha$-amylase inhibitory activities of nine Sri Lankan anti diabetic plants. British J. Pharm.Res. 2015;7(5):365-74.

22. Gladis R M C, Chellaram C. Effets inhibiteurs de l'alpha amylase et de l'alpha glucosidase desextraits de tige de Salacia oblonga et son analyse GC-MS. Braz. J. Pharm. Sci. 2018;54 (1) : e17151

23. Chang-Yong Y, Jing W, Yuan Z, Xing J, Zhen-Guo $X$. Anti-diabetic effects of Panax notoginseng saponins and its major anti-hyperglycemic components. J. Ethnopharmacol 2010; 130:231-6.

24. Fang X K, Gao Y, Yang H Y, Lang S M, Wang Q J, Yu B Y, Zhu D N. Alleviating effects of active fraction of Euonymus alatusa bundant in flavonoids on diabetic mice. American Journal of Chinese Medicine Journal2008;36(1): 125-140. Doi:10.1142/S0192415X08005643.

25. Kouadio B, Djeneb C, Yao K, Guédé N Z. Potentiel antiradicalaire des extraits de feuilles de Bersama abyssinica Fresen. (Melianthaceae). Int. J. Biol. Chem. Sci. 2017;11(6):2962-2970.

26. Li H B, Cheng K W, Wong C C, Fan K W, ChenF, Jiang Y. Evaluation of antioxidant capacity and total phenolic content of different fractions of selected microalgae.

Food Chemistry2007;102:771-776.

27. Javanovic S V, Steenken S, Tosic M, Marjanovic B, Simic M J. Flavonoidsas antioxidants. Journal of the American Chemical Society1994;116:4846-4851. 


\section{How to cite this article:}

Ernest Rodrigue Talla, Fidèle Ntchapda, Emmanuel Talla, David Miaffo and David Romain Azambou Kemeta. 2021. Anti-radical Properties of the Aqueous Extract from the Trunk Bark of Crateva adansonii (Capparaceae) and their role in the Inhibition of $\alpha$-amylases and $\alpha$ glucosidases Activities during the Carbohydrate Digestion. Int.J.Curr.Microbiol.App.Sci. 10(06): 697-709. doi: https://doi.org/10.20546/ijcmas.2021.1006.077 